Spring 1995

\title{
Flexible Exams in the Introductory Legal Environment Course
}

Susan L. Martin

Follow this and additional works at: https://digitalcommons.fairfield.edu/nealsb

\section{Recommended Citation}

Martin, Susan L. (1995) "Flexible Exams in the Introductory Legal Environment Course," North East Journal of Legal Studies: Vol. 3 , Article 10.

Available at: https://digitalcommons.fairfield.edu/nealsb/vol3/iss1/10

This item has been accepted for inclusion in DigitalCommons@Fairfield by an authorized administrator of DigitalCommons@Fairfield. It is brought to you by DigitalCommons@Fairfield with permission from the rightsholder(s) and is protected by copyright and/or related rights. You are free to use this item in any way that is permitted by the copyright and related rights legislation that applies to your use. For other uses, you need to obtain permission from the rights-holder(s) directly, unless additional rights are indicated by a Creative Commons license in the record and/or on the work itself. For more information, please contact digitalcommons@fairfield.edu. 
H. E. Peters, "Marriage and Divorce: Informational Constraints and Private Contracting, American Economic Review. Vol. 76, No. 3, June 1986, pp. 437-454.

Borenstein, Severin and Paul N. Courant, "How to Carve a Medical Degree: Human Capital Assets in Divorce Settlements, "American Economic Review, Vol. 79, No. 5, December 1989, pp. 992-1009.

\section{NATURAL RESOURCES, VALUATION AND ALLOCATION ISSUES}

Hope, Natural Resource Damage Litigation Under CERCLA. 14 Harv Envtl. L. Rev. 189 (1990)

Ohio v. U.S. Department of Interior, 880 F.2d 452 (D.C. Gr. 1989).

Yang, Valuing Natural Resource Damages: Economics for CERCLA Lawyers, 14 Envtl. L. Rep. 10311 (1984).

Cicchetti and Peck, Assessing Natural Resource Damages: The Case Against Contingent Value Survey Methods, Nat. Resources \& Env't., 4 Spring, p. 6 (1989)

Landreth and Ward, Natural Resource Damages: Recovery Under State Law Compared With Federal Laws. 20 Envtl. L. Rep. 10134 (1990)

State of Idaho v. Bunker Hill Co. 635 F. Supp. 665 (D. Idaho 1986).

Cutler Cranberry Co. Inc. v. Oakdale Electric Cooperative, 78 Wis. $2 \mathrm{~d} 222$, 254 N.W.2d 234 (1977)

Trial Transcript Excerpt of Cutler Cranberry v. Oakdale, 20 P.O.F. $2 d 165$ (19)

Frankfurt Oil Co. v. Abrams. 413 P.2d 190 (1966).

Culpepper v. Federal Crop Insurance Corp. 274 So.2d 815 (La. App. 1973).

\section{FLEXIBLE EXAMS IN THE INTRODUCTORY LEGAL ENVIRONMENT COURSE}

by

Susan L. Martin

Introduction

Although testing is a most important aspect of the teaching and leaming process, most business law professors have had little preparation in designing evaluation tools. To address this problem which exists for professors in most fields, many articles have been written about choosing an appropriate exam format and constructing meaningful exams. Unfortunately, mere proficiency at creating a particular kind of test no longer seems adequate. No one exam type seems to assess well the leaming of an increasingly heterogeneous mix of students. Equally important are students' perceptions that they cannot do well on certain types of exams.

After reviewing the usugl exam formats used in business law classes, this article concludes that because of the wide variations in abilities of students and the time constraints on professors, a multiple-clioice exam that allows students to respond in essay form can be a useful tool.

Assessing Students

Generally, instructors of an introductory legal environment course test students to assess several areas of achievement. First, instructors want to know that students

"Associate Professor Business Law, Frank G. Zarb School of Business, Hofstra University. 
have mastered the substantive content of the course. Examples of this kind of leaming might include knowing what jurisdiction means; knowing what provisions employers must mist make sites. In addition instructors expect students to exists for the clean up of toxic waste sites. In addition, instructors expect students to demonstrate that they can use the knowledge they bave acquired to solve new problems. This skill would be required to explain, for example, how a new case prould be decided based on past precedent. Instructors might also want to assess the attitudes and values students bave acquired in connection with business law concepts.

Although constructing meaningful testing instrments has never been a simple tack the job has aotten much more difficult because of the increasingly wide variations in in the abilities of students in many collegiate institutions. Because of these demonstrate their command of the material taught. Although each format has its advantages and drawbacks, each favors and disadvantages different kinds of students. Thus, the instructor is presented with an enhanced problem of grading students fairly and having them perceive that they have been graded fairly. The leaming environment is hampered when stadents feel that although they knew the material, they were not able to demonstrate that knowledge on an exam.

In addition, the instructor's own interest is undermined when students believe that their exam grades do not reflect their mastery of the course work. Colleges and universities are putting increasing emphasis on teaching perfornance. ${ }^{2}$ Usually, an important element in assessing teaching ability is student evaluation data. ${ }^{3}$ Therefore, instructors facing reappointment, tenure and promotion decisions have a personal instructors facing reat that makes them feel unable adequately "show what they know."

\section{Exam Formats}

\section{Essay Exams}

Essay exams are probably the inost obvious choice for business law professors. It is the way they were tested in law school. Moreover, essay exams have significant strengths. ${ }^{4}$ They can test complex learning outcomes, such as organizing and writing about leamed material, that cannot be tested in other formats. Essays are an effective means of testing students' ability to think critically and apply what they have learned in means of testing students ability to think critically and apply what hey have learibitity of answering correctly by merely guessing. As a practical inatter for the instructor, essay exams cal be created rather quickly. Nevertheless, essay tests also have important limitations.
First, various studies have demonstrated the unreliability of essay exams. ${ }^{5}$ Different graders may score the same response differently and even the same grader may score responses differently at different times. The response to one question may also influence the grader's assessment of the student's response to another question on the same exam. Moreover, the grader's assessment may be influenced by factors other than what is purportedly being tested, for example, handwriting, spelling or grammar. Second, becanse essay questions take relatively long to answer, only limited subject matter can be tested. Thus, the student who studied the "right" material may do better than the student who has more comprehensive knowledge but who, unfortunately concentrated on material not covered on the exam.

Third, although essay exams may be constructed more quickly than other formats, they are very time consuming to grade. Not only does it take long to read students' essays once, but ideally, they should be read and scored twice with the grade being the average of the two. ${ }^{6}$ Such a process will increase the exam's reliability. Furthermore, for the exam to be a leaming experience, comments slould correct erroneous statements, note omitted and irrelevant responses, and point out other errors in logic, grammar, spelling, etc. The practical reality for the professoriate is that professional success (reappointment, tenure, promotion) is measured by excellence in teaching, publication and service (to the department, the school, the university), none of which is deternined by time spent grading exams. In fact, time spent grading exams specifically and directly limits time that can be spent on publishable research and service activities. Even actual and perceived teaching skills are not necessarily related to time spent grading exams. Essay exams may actually lower students' perceptions of a professor's teaching ability because grading is necessarily subjective and open to interpretation: the student's interpretation may vary significantly from the instructor's. It may be difficult for the poorer students to understand nuances that have made the exam responses of others rate higher grades than their own.

In addition, the disadvantages of essay exams have increased because of changes in students of collegiate business studies. Demographics, institutional financial considerations, affirmative action programs and a larger number of foreign students all play a role in creating the great variation of abilities among students. An instructor of the introductory legal studies course may have students with very poor writing skills. Because of the large amount of substantive material that is covered in this kind of course, there is little time to devote to teaching the test-taking techniques that are necessary to approach an essay question successfully. Furthermore, significant numbers of foreign students may have such a poor cornmand of written English that it is almost impossible for them to demonstrate in an essay, particularly in a limited time period, their understanding of the substantive material. 
Some business law professors, in an effort to achieve the advantages of an essay exam, particularly avoiding having the mere guess produce the correct answer, while limiting the disadvantages of unreliable and time consuming grading use the short form essay exam. ${ }^{7}$ In this form, instead of being open ended, questions are very focused and require a one, two or three sentence response. This format generally will yield a more reliable score than long open-ended questions. ${ }^{8}$ Restricted response questions are also more appropriate for testing content because, unlike typical extended response essay questions, they do not leave students free to determine wbat content they want to include in their answer. This format is also more amenable to students with limited writing skills or a limited command of the English language.

Unfortumately, the more suitable the short essay question is for the latter students, that is, the shorter the required response, the more uncomfortable it will make students who read into a question and need room to explain fully.

\section{Multiple-Choice Exams}

Multiple-choice exams (and other objective variations such as true-false, matching and fill-ins) are often the exam of choice because they can be scored quickly and efficiently by machine; however, professors seem to be apologetic about their use. according to experts, this guilt is unwarranted. ${ }^{9}$ Multiple-choice questions are not necessarily merely superficial, "multiple-guess" exercises. choice items may be used to test the same higher levels of learning, analysis, synthesis and evaluation, that an essay exam appraises. In addition, multiple-choice questions can test more material because more questions can be asked than on an essay exam. Luck in choosing the "right" material to study, is neutralized as a factor contributing to success on the exam.

Nevertheless, multiple-choice and other objective format exams have distinct weaknesses. It is difficult to construct multiple-choice questions that are completely without ambiguity. Students may read more into a question than was intended. This may disadvantage students who actually have broader or deeper knowledge. Furthermore, multiple-choice items may require fine distinctions that students perceive to be too subtle and therefore, unfair. Distinguishing between options may also require good reading skills. Just as increasing numbers of students have insufficient writing skills, some are deficient in reading skills. Thus, there are students who can explain business law concepts in their own words, but who have great difficulty choosing the correct answer from among several options.

\section{Flexible Exams}

The foregoing brief review of essay and multiple-cboice exams suggests that every student will not be able to demonstrate his or her ability to understand, apply, analyze, synthesize and evaluate legal concepts on one kind of exgm. The short essay format is one way of trying to achieve the advantages of both essay and multiplechoice items without the disadvantages of either. Another possibility is adapting the multiple-choice question to an essay format. This method does not eliminate the time consuming task of creating well designed multiple-choice questions, but it does make scoring a relatively easy task and it greatly improves student satisfaction and perception of fairness.

Students are given an ostensibly multiple-choice exam with the following instructions: "Choose the best answer. Mark your response in the appropriate space on the answer sheet. You may answer any question(s) in essay form in the blue book." The instructor explains to the students that multiple-choice questions may contain unintended ambiguities and the blue book gives thern the opportunity to answer such questions correctly even though they find none of the provided options satisfactory. Enough time is scheduled for the exam so reading and writing speed is not a significant factor in completing the exam. Thus, students bave the opporturity to address a question in the way that suits them best. Any question answered correctly on the answer sheet is marked correct. For every incorrect answer sheet response, the instructor checks the blue book to see if an explanation has been given. Students may explain why none of the choices are satisfactory, wby more than one choice is satisfactory, or even their general understanding of the area of the law addressed in the question. They may get full credit or partial credit for their blue hook responses. They get no credit for marking the wrong answer on the answer sheet and then merely iterating a second provided option in the blue book. Foreign students unable to write well in English and others with poor writing skills may choose not to use the blue book at all. Students with poor reading skills who have difficulty selecting one option among several, may explain their responses im their own words.

\section{Results of Using Flexible Fomat Exams}

Students in the introductory legal environment course at the Hofstra University School of Business, given exams im a flexible format during seven semesters, Fall 1990 through Fall 1993, have been overwhelmingly satisfied with the format. In four of those semesters a questionnaire was adninistered after students had taken two midterm exans but before they had taken a final exam. Table 1 indicates responses of 
students to the question, "Do you like the flexible format exam as opposed to a multiple-choice exam or an essay exam?"

TABLE 1

\begin{tabular}{|c|c|c|c|c|c|c|}
\hline Semester & $\stackrel{\#}{\text { Responding }}$ & $\begin{array}{c}1 \\
\text { Like } \\
\text { Formal } \\
\text { Very Much } \\
\% \\
\end{array}$ & $\begin{array}{c}2 \\
\text { Like } \\
\text { Format } \\
\%\end{array}$ & $\begin{array}{l}{ }^{3} \\
\text { Neurral } \\
\text { About } \\
\text { Fommat \% }\end{array}$ & $\begin{array}{c}4 \\
\text { Dislike } \\
\text { Fonmal } \\
\%\end{array}$ & $\begin{array}{c}5 \\
\text { Disilike } \\
\text { Format } \\
\text { Very Much } \\
\% \\
\end{array}$ \\
\hline \multirow{4}{*}{ Fall 1990} & 29 & 68 & 12 & 16 & - & 4 \\
\hline & 34 & 91 & 3 & - & - & 6 \\
\hline & 25 & 70 & 4 & 13 & - & 13 \\
\hline & 26 & 84 & 4 & $\cdot$ & - & 12 \\
\hline \multirow{4}{*}{ Fall 1991} & 32 & $\overline{82}$ & 11 & 7 & $\cdot$ & - \\
\hline & 28 & 58 & 31 & 4 & 8 & - \\
\hline & 30 & 42 & 38 & 15 & - & 4 \\
\hline & 25 & 71 & 25 & 4 & - & - \\
\hline \multirow{3}{*}{ Fall 1992} & 30 & 81 & 12 & $\cdot$ & - & 8 \\
\hline & 56 & 90 & 6 & - & 2 & 2 \\
\hline & 33 & 97 & $\cdot$ & - & 3 & $\because$ \\
\hline \multirow{2}{*}{$\begin{array}{l}\text { Spring } \\
1993\end{array}$} & 35 & 91 & 6 & 3 & $\cdot$ & - \\
\hline & 40 & 82 & 13 & 5 & - & $\therefore$ \\
\hline
\end{tabular}

Students were also asked what grade they expected to receive for the semester. In the Fall 1989 semester when traditional multiple choice and essay exams were used, the mean expected course grade was a "B". In the four semesters listed in Table I when flexible format exams were given, the mean response to that question was also a "B". Thus, students' preference for the flexible exam does not seem dependent on their perception that the format would result in their receiving higher semester grades. The format does seem to lower student anxiety levels. Some students are uncomfortable with multiple-choice exams because a machine-scored answer sheet does not allow them to add "but ..." to a response. The flexible format permits that. One clear anecdotal result of using the flexible format is the almost complete absence of student complaints about exams, particularly about ambiguous questions or arbitrary grading. The "blue book option" provides a safety net for both the student and the instructor. Time required for grading is much less than that required for an essay exam. As a practical matter, many students choose not to use the blue book at all. Often when students respond in the blue book, it is to iterns they have gotten right on the answer sheet. Nevertheless, there are always students who get credit for essay responses that indicate their understanding of the material although they have chosen the wrong answer on the answer sheet. They may have misread the stem of the item or failed to distinguish among the options. They may have misunderstood a word that the instructor assumed was readily understandable. In addition, blue book responses, and those questions to which there are no blue book responses, provide feedback for the instructor that is helpful in creating new test items and in preparing lessons.

\section{Conclusion}

The flexible format exam appears to be a useful testing tool that relieves student anxiety and is perceived as fair by an increasingly heterogeneous student body. It is also efficient for the instructor because grading time is considerably less than that required for essay examinations.

\section{ENDNOTES}

I George D. Cameron In \& Cindy A Schipani An Altemative to the Tradifional Objective and Essay Examination Fomots in Busimess Low, $9 \mathrm{~J}$. LEGAL STUD. EDUC. 105 (1990); David A. Frisbie \& Kristie K. Waltman, Developing a Personal Grading Plon, EDUC. MEAS.: IssuEs \& PRACTICE 35 (Fall 1992); Richard J. Stiggins, High Quality Classroom Assessment: What Does It Really Mean?, 11 EDUC. MEAS.: IsSUES \& PRACTCE 35 (Summer 1992).

2 See e.g., TEACHING EVALUATTON HANDBOOK, Office of Instructional Support, Comell University (1993).

3 Id. at $28-29$.

4 See Willian E. Cashin, Improving Essay Tests, IDEA PAPER No. 17, Center for Faculty Evaluation \& Development, Kansas State University (Jan. 1987).

$5 \quad$ Id

$6 \quad$ Id.

7 See, e.g., Cameron \& Schipani, supra note 1, at 105-106.

8 See, e.g., Cashin, supra note 4. 
See eg. Victoria L Clegg \& Wiliam E. Cashin Improving Multiple-Choice Tests, IDEA PAFER No. 17, Center for Faculty Evaluation \& Development, Kansas State University (Sept. 1986)
WHY CAN'T WE HAVE BETTER QUESTIONS: A CRMTICAL EVALUATION OF THE UNIFORM CPA BUSINESS LAW EXAMINATION OBJECTIVE QUESTIONS, YEARS 1988-1993

by

Arthur M. Magaldi*

As life in the latter stages of the twentieth century has become more complex and financial transactions more intricate, the role of the accountant has grown in importance. With financial and economic complexity has come the need to independently verify the assertions of those involved in business transactions. Indeed, stahutes often require that parties submit audited financial statements, for example, when registering a new issue of securities with the SEC for sale to the public by ineans of interstate commerce." In other transactions like loans to businesses, audited financial statements are routinely required. In many ways, CPAs are considered the guardians of the financial integrity of our institutions.

As the accounting profession has grown in importance, the Uniform CPA Exarnination has similarly become more important. "The Uniform CPA Examination is the primary means used by the boards of accountancy to measure the technical competence of CPA candidates. To understand the importance of the examination as a prerequisite for the CPA certificate, one must recognize the significance of the certificate. It is awarded in the public interest to qualified candidates in accordance with the accountancy statutes of a given jurisdiction. The certificate is granted to ensure the professional competence of individuals offering their services to the public as professional accountants."

The Uniform CPA Examination is given each year in May and November and has four distinct parts. A candidate must show competency in all four parts of the

"Professor of Law, Pace University. 